\title{
FREIGHT TRANSPORT USING HIGH-SPEED RAILWAYS
}

\author{
INARA WATSON, AMER ALI \& ALI BAYYATI \\ School of the Built Environment and Architecture, London South Bank University, UK
}

\begin{abstract}
There has been an encouraging awareness of the need for more sustainable transportation particularly for freight transport that has resulted from the continuing increases in global trade and business internationalisation. This is mainly driven by the related issues concerning greenhouse gas emissions and dependency on fossil fuel. The expansion in the worldwide high-speed railway (HSR) systems has provided a reliable opportunity for freight transportation. The HSR has the ability to move goods in a more efficient, safe and cost-effective way, which can improve trade links in Europe and the rest of the world. Many countries have developed HSR systems, but such systems are mostly used for passenger transport despite their haulage capacity. This research investigates the future possibility of shifting freight from airlines onto HSR, by analysing the operational and technical constraints associated with freight traffic. Most of the data were gathered from online sources and related research publications concerning a selected set of worldwide HSR systems. The outcome of this research may contribute to the development of suitable solutions that may improve the economic, environmental and social sustainability of transport systems.
\end{abstract}

Keywords: freight transport, high-speed railways, sustainability

\section{INTRODUCTION}

The worldwide increases in trade and related activities mean that freight needs to be transported over long distances in a more sustainable way. Freight also has a tendency to move from areas of specific economic activities, industrial areas and ports to centres that have a high density of population. The increasing amount of express delivery offers the opportunity for high-speed railway (HSR) to play a significant role in this supply chain. Deploying the HSR to transport time-sensitive and high-value freight can have substantial impact on the short-haul aviation market. The HSR provides significant number of seats for passengers and can also provide large capacities for freight. The HSR may transport freight on short and medium distances to relieve congestion at airports. The average flight route distance in Europe is around 500-600 km. Such distance means that the HSR can be very competitive with air transportation. In order to develop an effective HSR, there is a need for huge investment. The majority of HSRs are unprofitable, but shifting the high-value and time-sensitive freight from air and road onto HSR can sufficiently increase the load factor of HSR lines and increase the revenues of HSR systems in addition to reducing the external costs of building and operating HSRs. Express operators barely cover the cost of air fares in express delivery, and they are looking for a more economical way of transportation. The operational cost of HSR is much less than that of air transport in addition to the fact that shifting freight to HSR will reduce the transportation costs, congestions and emissions. Building new airports or expanding existing ones may not be the solution for the transportation problems. The solution must lay in an integrated approach of transportation when transport modes, instead of competition, work together and complement each other. The aim of this research is to investigate the future possibility of shifting freight from roads and airlines onto HSR by analysing the operational and technical constraints associated with freight traffic. The secondary data methodology has been used to prepare this paper. Most of the data were gathered from online sources and related research publications concerning a selected set of worldwide HSR 
systems. The outcome of this research contributes to the developing of suitable solutions for freight transportation that may improve the economic, environmental and social sustainability of transportation modes.

The remainder of this paper is organised as follows: Relevant literature is reported in Section 2, whilst Section 3 describes the increases in demand for express delivery services. Section 4 discusses the growing congestions at airports. The current situation concerning freight transportation by HSR and the concept for freight transportation using HSR are reported in Section 5. Discussion and conclusions are given in Section 6.

\section{LITERATURE REVIEW}

There has been a relatively limited number of publications on freight transport using HSR. In general, this may be reflected in the decreasing share of freight transported by railways in many parts of the world. However, the continuing increases in the rapid online shopping and delivery mean that HSR systems have a huge opportunity to increase its share of freight transport. Ruamsook [1] reported that the most environmentally damaging element of supply chains is freight transportation. In the majority of cases, transportation produces greenhouse gas emissions, and it is mainly dependent on fossil fuel. The future of freight transportation will lie in two dimensions, first its on-time delivery and second its minimum environmental impact. Current strategies for reducing environmental impact depend on new technological solutions that are employed to manage existing infrastructure network. The improvement in vehicle technologies gives some benefits, but the future challenges must lie in promoting the modal shift. The authors put forward ideas about joint economic-environmental sustainability of freight transportation.

The published research on freight trains using HSR can be divided into two parts. The first part looks at opportunities to use the existing HSR network for freight trains to transport highvalue and time-sensitive goods, whilst the second part is set for studies concerning the design and building of new HSR lines which are dedicated for freight trains only. China, the country with the largest HSR network, has developed new types of freight train for speeds of 250-350 $\mathrm{km} / \mathrm{h}$. Yu et al [2] reported on the design of a two-stage model for the HSR cargo express operation which meets the needs of technical and economical requirements of train operation. The first-stage model considers the line capacity, loading restrictions and origin-destination demand. The second stage considers the economic efficiency of train operation. The authors admitted that the market share of HSR cargo express trains in China is less than $1 \%$. However, Yu et al [2] concluded that HSR freight trains have high efficiency and low pollution and can help reduce the external costs. HSR has a large capacity, high punctuality and high safety with low energy consumption for operation. Huang and Shuai [3] developed a model for the selection of HSR station as hubs for express freight transportation. They considered a number of influencing factors such as GDP, population and number of large enterprises. Increasing the share in high-value goods transported by HSR will significantly improve the efficiency of HSR, increase railway income and raise the HSR image. The development of HSR lines will be the opportunity to shift freight to release the conventional rail network and use HSR for express delivery of high-value goods, particularly overnight. Liang et al [4] compared the business model, organisation of transportation and performance of Germany, France and China in transporting parcels by the HSR network. The authors suggested that the dedicated high-speed trains are better than mixed trains. However, there must be enough demand for these types of train. With a small increase in the marginal operational costs on the routes where there is less 
passenger demand, part of the carriages of the electric multiple units (EMU) can be used to transport express freight. This will help improve the train utilisation rate.

An interesting approach to transport freight by HSR is reported by Pazour et al [5]. The USA accounts for $26.4 \%$ of rail freight transport worldwide with over $250,000 \mathrm{~km}$ of railway network. Pazour et al [5] investigated the potential impact of developing HSR for freight transportation on the transport system of the USA. Implementing such concept may reduce congestion and decrease travel time on highways of continental USA. The authors developed a model to design efficient HSR network between major cities in the USA and analysed its impact on the current highway system. With the increasing number of express delivery and just-in-time practices, the project attracted huge interest. Although they developed a modelling approach for improving transportation in the USA, such approach can also be used to improve the railway connectivity between China and Europe.

Behiri et al [6] investigated the integration of urban freight transport with passenger rail network. A large percentage of road transport in cities around Europe is related to freight transportation which causes congestion, pollution and accidents. The authors developed optimisation methods to solve the train, rail and station-sharing problem for passenger and freight transportation.

\section{INCREASES IN DEMAND FOR EXPRESS DELIVERY SERVICES}

The globalisation has increased the amount of goods, services and capital that move across borders. A number of small sized goods that are being transported around the world in recent years have raised interest in developing high-speed freight trains [7]. DHL, FedEX, TNT and UPS are the four largest players in the global express industry [8]. These companies offer door-to-door on-time delivery, offer possibility to change the destination and address in transit and possibility to track parcels through every step of its journey. At present, the express freight transportation in Europe is divided between aircraft and road vehicles. In 2016, air cargo transported 53.9 million tonnes which represent approximately $35 \%$ of global trade by value. Air transport carries $\$ 15.3$ billion worth of goods every day [9]. DHL delivers approximately 5.1 million tonnes of express cargo annually by air in Europe. DHL has over 17,000 scheduled departures per week. In the UK, DHL has 30 aircraft, 24 of them are Boeing 757 and 6 Boeing 767 [10]. The maximum payload of Boing B737 is between 19 and 100 tonnes depending on the type of aircraft [11]. To transport 5 million tonnes of express delivery freight only in intra-Europe, a hundred thousand flights per year are needed. The express delivery industry very much depends on overnight transportation, and in this case, HSR can have a good opportunity to expand business by offering express freight services. The express services industry uses a variety of different transportation modes, and HSR can be one of them. In the USA, the express delivery service in 2003 accounted for over $60 \%$ of the domestic air cargo market. Intra-Europe express market response is $34 \%$ of the global express market [8]. Shifting freight from roads and air to railways can reduce congestion on roads and airports, reduce the amount of fuel used by the transport industry and reduce greenhouse gas emissions. A tonne of freight carried by a train produces $90 \%$ less carbon dioxide emission compared to road transportation [12]. Furthermore, taking lorries from roads will be a substantial reduction in the accidents and road maintenance costs. Fuel oil is a finite mineral resource, and prices on the oil market inevitably will increase. It was estimated that costs of freight transported by roads will increase by $36 \%$ by 2040 [13]. In 2015, the biggest four online shopping markets in the world were the UK, the US, Germany and China. Share 
of online market will double in size by 2018 [14]. The goods transported by air accounts for only $3 \%$ of the total freight weight but hold $40 \%$ of the total value [18]. The online market is growing. In Western Europe, online sale increased from $£ 174.76$ billion in 2015 to $£ 262.46$ billion in 2018, whilst in the USA, it increased from $£ 269.46$ billion in 2015 to $£ 408.74$ billion in 2018 [15].

The online sales increase by approximately $14 \%$ year on year. The UK, Germany and France dominated the European market, and they are responsible for $75.1 \%$ of the total online sales in Europe. Fifty-two per cent of the population in Europe and $66 \%$ of the population in the USA shop online. British retailers are the most popular for German consumers and second most popular for China and the USA consumers [14]. In Europe, express services deliver approximately 260 million packages each year and move approximately six million packages everyday worldwide. Growth rate is between $25 \%$ and $35 \%$ annually, and international trade is expected to increase by approximately 70\% between 2009 and 2019 [16]. Trade in goods between the EU and China increased from $€ 466$ billion in 2014 to $€ 514$ billion by 2016 which represents an annual average increase of $4.2 \%$ [17]. The online shopping market in China in 2014 reached 2.8 trillion CNY (China Yuan) and has an annual growth rate of $48.7 \%$ [4]. Rapidly growing online market in Asia-Pacific region overtakes the USA, reaching $\$ 500$ billion [18].

Expanding the online retail market increases the share of express delivery services, whilst the air cargo market will grow by $7 \%$ year on year [19]. One third of high-value goods transported between China and Europe is transported by air [20]. In the future, the importance of express delivery services will only increase as world economy becomes more integrated and express delivery services minimise the inventory costs.

\section{THE GROWING CONGESTIONS AT AIRPORTS}

In 2015, around 3.5 billion passengers travelled by air with 34 million scheduled departures. It was predicted that by 2030, these figures will be doubled [21]. Most of the airports in Europe are inefficient with a growing congestion and shortages of capacity [22].

Table 1 shows the four busiest airports in Europe with an average punctuality of around $68 \%$. 'On time' is considered as arrival or departure of not more than 15 minutes after scheduled time. In 2017, the Paris Charles de Gaulle Airport in France was the most delayed major airport in Europe. Frankfurt Airport is another busy hub connecting inter- and intra-flights in Europe. With the scarcity of available land around the airports in Europe and technical and safety requirements, it is difficult to expand airports. One of these examples can be Heathrow Airport. Some airlines are trying to solve this problem by reducing the frequency of flights and increasing the capacity of airplanes, but this will require an increase in the length of runways. As a result of the increasing wealth and population, the number of future journeys will

Table 1: Busiest airports in Europe in 2017. Source: [23], [24].

\begin{tabular}{llcc}
\hline Rank & Airport & Total passengers & Punctuality (\%) \\
\hline 1 & London Heathrow Airport (UK) & $77,987,524$ & 70.2 \\
2 & Paris Charles de Gaulle Airport (France) & $69,471,442$ & 66.1 \\
3 & Amsterdam Airport Schiphol (Netherlands) & $68,515,425$ & 68.1 \\
4 & Frankfurt Airport (Germany) & $64,500,386$ & 66.2 \\
\hline
\end{tabular}


Table 2: Air freight and mail transport by selected countries in Europe in 2016, freight and mail loaded/unloaded (in tonnes). Source: [25].

\begin{tabular}{lllll}
\hline \multirow{2}{*}{ Country } & \multicolumn{2}{l}{ National transport } & \multicolumn{2}{l}{ International intra-EU transport } \\
\cline { 2 - 5 } & $\begin{array}{l}\text { Volume of } \\
\text { freight and } \\
\text { mail }\end{array}$ & $\begin{array}{l}\text { Growth 2015-2016 } \\
(\%)\end{array}$ & $\begin{array}{l}\text { Volume of } \\
\text { freight and mail }\end{array}$ & $\begin{array}{l}\text { Growth 2015- } \\
2016(\%)\end{array}$ \\
& 193,373 & -4.2 & 652,332 & 15.5 \\
France & 122,372 & 4.6 & $1,077,847$ & 5.4 \\
Germany & 39,328 & -12.6 & 286,029 & 2.9 \\
Italy & 59,961 & 4.1 & 187,146 & 5.1 \\
Spain & 96,607 & -9.1 & 457,037 & 8.1 \\
United Kingdom & & & & \\
\hline
\end{tabular}

only increase. Building new airports or expanding existing ones is not the best solution. The solution must lay in an integrated approach for transportation when transport modes, instead of competition, will work together to complement each other.

Table 2 shows the increase in air freight and mail transportation in selected countries in 2016. In 2017, the total amount of cargo loaded and unloaded by airports worldwide increased by $7.9 \%$ [26]. There is an obvious increase in freight transportation by air. Boing estimated that in 2017 , there were 1,870 freighters in operation, and by 2037 , it will increase to 3,260 freighters. The main flight route distance in Europe is around $500-600 \mathrm{~km}$, and a proportion of routes where a hub is at an end or at a start point is around 50\% [27]. The hub is a specialised airport with large cargo facilities where freight can be loaded, unloaded and transferred. Usually, the hub is located in the centre of the large industrial area. There are increases in awareness concerning the negative environmental impact from using fossil fuel, and people are getting less tolerant to continuous increases in noise levels, whilst airports suffer from scarcity of available land around them. These factors force the air transportation authorities to look for more sustainable ways to do business. One of the ways could be the replacement of short-haul flights by HSR. HSR has a huge opportunity to take an effective role in the supply chain of high-value and time-sensitive freight. HSR can help reduce the congestion at airports by transporting freight and passengers on the next leg of their journeys.

Table 3 shows the selected airports in the EU-28 in terms of total freight and mail loaded/ unloaded in 2016 (tonnes). The Paris Charles de Gaulle airport is the main airport in the EU for transporting freight and mail. Heathrow airport has only 2,000 freight flights as $95 \%$ of Heathrow's cargo is transported by passenger aircraft. In the EU, between 2015 and 2016, there was a $6.8 \%$ growth in international air freight transportation and 3.9\% in air mail transportation [25]. In the future, the growing number of passengers and increases in freight volumes in Europe mean that EU airports will be operating 24/7 and 365 days per year. For example, Boeing will increase the number of freighters from 1,870 in 2017 to 3,260 by 2037, whilst the highest increase in freight carriers will be for their 757's and 737's with a capacity of less than 45 tonnes [29]. There is an increasing demand for express delivery. Presently, air-road transport fulfils this demand. Nevertheless, transport delivers a huge contribution to rising greenhouse gas emissions and brings a threat to biodiversity and human health. A 
Table 3: The selected airports in the EU-28 in terms of total freight and mail loaded/ unloaded in 2016 (tonnes). Source: [28].

\begin{tabular}{|c|c|c|c|c|c|c|}
\hline Rank & Country & Airport & $\begin{array}{l}\text { Total air } \\
\text { transport } \\
\text { (tonnes) }\end{array}$ & $\begin{array}{l}\text { Growth of total } \\
\text { freight trans- } \\
\text { port } 2015- \\
2016(\%)\end{array}$ & $\begin{array}{l}\text { Total number } \\
\text { of freight } \\
\text { flights }\end{array}$ & $\begin{array}{l}\text { Growth of } \\
\text { total number of } \\
\text { flights } 2015- \\
2016(\%)\end{array}$ \\
\hline 1 & FR & $\begin{array}{l}\text { Paris/Charles } \\
\text { de Gaulle }\end{array}$ & $2,211,265$ & 5.8 & 28,000 & -1.5 \\
\hline 2 & $\mathrm{DE}$ & $\begin{array}{l}\text { Frankfurt/ } \\
\text { Main }\end{array}$ & $2,111,358$ & 1.7 & 21,000 & -0.7 \\
\hline 3 & NL & $\begin{array}{l}\text { Amsterdam/ } \\
\text { Schiphol }\end{array}$ & $1,771,106$ & 7.0 & 17,000 & 4.9 \\
\hline 4 & UK & $\begin{array}{l}\text { London/ } \\
\text { Heathrow }\end{array}$ & $1,637,582$ & 3.1 & 2,000 & 2.5 \\
\hline 11 & $\mathrm{ES}$ & $\begin{array}{l}\text { Madrid/ } \\
\text { Barajas }\end{array}$ & 404,284 & 5.7 & 9,000 & 2.0 \\
\hline 18 & IT & $\begin{array}{l}\text { Roma/ } \\
\text { Fiumicino }\end{array}$ & 160,904 & 11.0 & 1,000 & -19.1 \\
\hline
\end{tabular}

global increase of emissions causes an increase in temperature around the world and, as a result, changes the climate. Road and air transport are a major source of greenhouse gases, and there is an urgent need to shift to a more sustainable mode of transportation. High-speed rail operates on the electrified network, and it can have zero carbon dioxide emissions, if it is using electricity from renewable sources. Shifting freight to high-speed rail can relieve the negative impact that transport has on the environment.

\section{THE CURRENT SITUATION AND CONCEPT OF HSR FREIGHT TRANSPORT}

There is a big opportunity for HSR to cooperate with air and road transport to replace shorthaul flights between airports by HSR. The HSR can also serve as a feeder for inter-continental air freight transportation. The length of HSR network increases day by day, as many countries have invested substantially in developing HSR which in 2017 reached 40,832 km [30]. The HSR network is growing internationally and links France, Belgium, Spain, the UK and Germany. In the future, there will be a similar connection between Italy and France. The majority of HSR lines around the world are dedicated to passenger traffic and mainly to one type of train. The construction of the HSR needs a huge investment. As the majority of the HSRs are unprofitable, shifting the high-value and time-sensitive freight from air and road to the HSR can sufficiently increase the load factor of lines, and this, in turn, increases the revenues of HSRs. It will also reduce the external costs of building and operating HSRs. The HSR operational cost is substantially less than that of air transportation. That means, shifting the freight from air to HSR will reduce the transportation cost which has been growing steadily in such a way that it is almost $10 \%$ of the purchasing cost. Express operators barely cover the cost of air fares, and they keep looking for a more economical way of transportation [31]. Travel time will play a crucial role in shifting freight from airlines to HSR, but it will depend on the distance between the freight terminals and airports in addition to the operational speed of the HSR. 


\subsection{The current situation of HSR freight transport}

Worldwide, there are 17 countries that have HSRs, but at present, most of these systems are designated to transport passengers, and they are not developed to carry freight [30]. The punctuality, resilience to weather conditions, cost efficiency and speed are the major factors that will help HSR to be a strong competitor to the freight carriers in Europe. Some countries already have the freight services that are operating on HSR, such as Italy, Germany and the UK. The freight services from Europe to London use HS1. In France, TGV passenger trains were converted into transport express freight on the railway network that links the north and south. The freight train TGV 'La Poste' had operated with a maximum speed of up to 270 $\mathrm{km} / \mathrm{h}$ since the $1980 \mathrm{~s}$, but recently, it was decided to stop such service because of the reduced number of postage and additional costs [32].

Lufthansa partly owns a carrier goods service company that buys capacity from DB running Inter Cargo-Express High Speed (HS) freight trains at speed up to $160 \mathrm{~km} / \mathrm{h}$. In Germany, the freight trains on HSR operate during the night with a fixed scheduled time. The night freight trains are very convenient for the express delivery companies. Parcels can be collected on the afternoon, transported during the night and then delivered in the morning. Railway transport produces almost three times less carbon dioxide emissions than road transport [33], and transporting by railway is $50 \%$ cheaper than by air and twice as faster than by sea [34].

In China, HSR has been used to deliver parcels since 2012. Express delivery services in China use the passenger EMUs which carry passengers in addition to parcels located in special luggage sections. Currently, in China, approximately 5\% of express cargo is transported by railways [4]. Presently, China is building new rolling stock (RS) for freight which will be used on HSR, and their design is based on the same principles as existing passenger bullet trains. China is developing two types of freight trains using HSR: super-fast with speed up to $300 \mathrm{~km} / \mathrm{h}$ and fast freight trains with speed up to $160 \mathrm{~km} / \mathrm{h}$. The super-fast freight trains would be competitive with air cargo, whilst fast trains would be competitive with road transportation [35]. These trains will use the HSR which was previously dedicated for passenger trains. China started developing a freight bullet train back to 2014. The freight trains will deliver high-value freight such as e-commerce parcels. In China, there is a strong tendency to reduce the bulk freight on railways and increase non-bulk freight.

The USA has only one HSR line from Boston via New York to Washington DC, Amtrak's Acela Services, where trains in some parts reach a speed of up to $240 \mathrm{~km} / \mathrm{h}$. Amtrak offers the freight express services by using their passenger trains to carry freight and post. The entire railway system in the USA is integrated in one railway network without any border crossings in comparison with railway networks in Europe, which are very fragmented with international borders and different topography from country to country. In the USA, on some of the Amtrak routes, revenues from express freight and mail traffic provide approximately $40 \%$ of the total revenue. Some of Amtrak long-distance trains carry more freight carriages than passengers. Apart from parcel and post, Amtrak transported special HS refrigerated carriages that can be coupled in one train with passenger carriages. They found that capacity of refrigerated carriages was approximately three times higher than if the Heavy Goods Vehicle (HGV) was used [36].

The first delegated freight high-speed train to become operational in Italy was in 2018. It connects the terminal Maddalone-Marcianise in Caserta in the south of Italy with Bologna Interport hub in the north. The operational speed of the train that consists of 18 tractor-trailers is $180 \mathrm{~km} / \mathrm{h}$. Freight is transported in rolling containers which accelerate the loading and unloading processes. Italian State Railways and Mercitalia Fast are planning to expand transportation of freight by HSR to other destinations in Italy [37].

Countries that are transporting freight by HSR are presented in Table 4. 
Table 4: Countries transporting freight by HSR (data taken from various resources).

\begin{tabular}{llll}
\hline Country & Speed $(\mathbf{k m} / \mathbf{h})$ & Rolling stock $(\mathbf{R S})$ & Type of freight \\
\hline Germany & $\leq 160$ & Converted from passenger RS & Post, Parcels \\
Sweden & $\leq 160$ & Modified freight RS & Post, Parcels \\
USA & $\leq 240$ & Modified freight RS & Post, Parcels \\
China & $\leq 360$ & Specially designed RS & Post, Parcels \\
Italy & $\leq 180$ & Specially designed RS & Rolling containers \\
\hline
\end{tabular}

\subsection{The concert of freight HSR services}

The freight HSR service concept includes:

- Establishing the intermodal and international demand of the freight with respect to the O-D flows.

- Developing origin-destination routes that include hubs and terminals and link them in one network.

- Transport mode cooperation principles, road-rail-air-rail-road, cooperation among separate systems. The HSR can be as a complementary mode to relieve congestions at airports or be part of the air transport services.

- Express freight HSR principles, mix or dedicated (e.g. transportation of freight in dedicated compartments of passenger trains, dedicated carriages or dedicated freight trains).

- Designing appropriate RS to match the demand for freight transportation by HSR. The carriages are dedicated only for freight or be dual-purpose that will allow altering according to the needs of passengers or freight.

- Offer a quality of service that will satisfy customers, as customers want to have parcels delivered on time and with acceptable posting costs.

The concept of freight transportation by HSR must also include a decision on delivery time and geographical coverage. The concept will support determining the routes that reduce the cost of transportation from origin to destination, reduce the environmental damages and satisfy the customers' service enquiries. Development of high-speed freight transportation will bring huge economic, operational and social opportunities for society. It can reduce the number of short cargo flights in Europe and reduce the number of lorries on roads and the resultant carbon dioxide emissions, in addition to attracting new enterprises to transport freight by HSR and to develop new freight terminals. The development of high-speed freight transportation will reduce the dependency on fossil fuel. It is important to mention that more than $60 \%$ of the population support an increase in freight transportation by rail [38].

The first step to shift freight from air to HSR will be to determine the origins and destination of freight flow and the corresponding routes. There will be a need to look at the two most important elements of the air-HSR system, namely, the development of multimodal terminals and coordinated timetables. Developing the air-HSR hubs and constructing new HSR links to airports will not only support the passenger transportation by HSR but overcome one of the barriers of developing freight services on HSR. The increasing speed and widening of the HSR network will make it more possible to collect parcels in the evening and delivering them 
the following morning across all Europe. The growth in the world's GDP and population will increase the demand for high-value goods and efficient transport services. DHL forecasted that by 2020 , online sales in the UK will grow by $600 \%$ compared to that of 2012 [39].

One of the undeveloped areas in shifting freight from air to HSR is the need to have a suitable RS. There are two ways to develop freight RS for HSR; it can either be converted from existing passenger trains to carry freight or developed for a dedicated freight RS. Developing new HSR RS can take up to 5-7 years. For technical and operational reasons, the axle loading for HSR freight carriages may need to be similar to that of passenger trains. In order to help reducing the loading and unloading time, HSR can use the same types of container that used for air freight carriers.

Consider Fig. 1. Most of the passenger HSR trains are fixed EMU trainset. To operate freight express services by HSR, trains can be divided into three different models. The first of these models presumes that the unit has some carriages that will be designated to transport passengers, but some of the carriages will transport freight. In the first model, when flow of freight is not stable, it can use specially designed EMU that can be easily converted to transport passengers or freight depending on the demand. The second model assumes that there will be different trainsets for passengers and for freight. The freight-dedicated EMU can be coupled with passenger EMU for some time to travel together. They have different starting and different destination points. During the travel time between origin and destinations, these freight units can be switched a number of times from one to another passenger train. Freight express EMUs can travel with passenger units in the day time and alone during the night time. This will reduce the freight delivery time and increase the utilisation of the RS and HSR infrastructure. The third model presumes that freight will be transported by dedicated EMU units that will travel alone from origin to destination. The number of carriages dedicated for freight can be fixed or variable. The type of trains-mix or dedicated freight will depend on the volume of goods.

Freight transportation by HSR can be relevant only if it does not affect passenger traffic. Also, there are needs to look for origin-destination pairs where the demand for freight can be in both directions from port to port or from airport to airport replacing short flights or long HGV journeys.

There are two ways to increase the HSR share in freight transportation, either increasing the number of hubs which connect air and HSR or ports and HSR or deploy HSR as the main transportation mode. At the design stage of the HSR station, there must be provided a storage

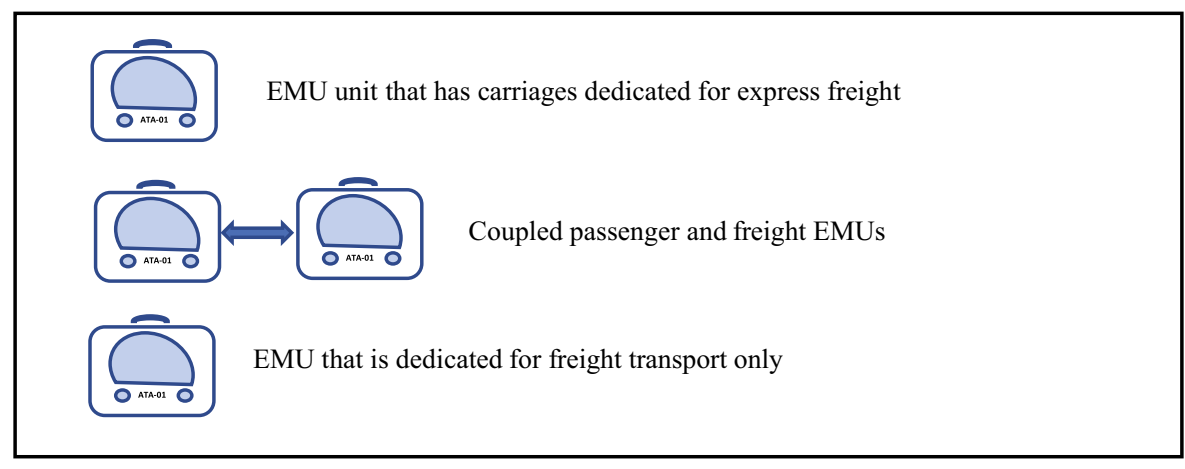

Figure 1: Three models of operating freight services on HSR (source: created by the authors). 
space for high-value and time-sensitive goods before and after they are transported by rail. It is very expensive to expand a station and build these areas once a station is built. Another option is to adapt the existing freight terminals for high-value, time-sensitive goods that would be transported by HSR.

Linking major air cargo and port hubs in Europe by high-speed freight transportation can be an alternative to short-haul air cargo routes or using the road transportation. This will reduce the carbon dioxide emissions, reduce the noise level, reduce the congestion on roads and at airports and improve the long-distance air cargo connectivity and safety on roads. Very often there are constraints on land due to the expansion of airports and highways. Railways use less land than roads or airports and offer more capacity. However, mixed traffic on HSR will have a considerably bigger effect on the maintenance of the infrastructure and will reduce the time that is available for maintenance. There will be a need for better coordination and cooperation among infrastructure managers when major maintenance is needed.

\section{DISCUSSION AND CONCLUSIONS}

There is an obvious change in the types of freight transported by railways, and there are needs to adapt to this situation. Worldwide, there is a new growing market created by the expanding use of the Internet and the increases in mobile shopping and e-commerce. The express delivery industry is growing rapidly as one of the fastest growing sectors of the economy, which means that there are new opportunities for express freight using HSR. With the growing and integrating global economy, share of guaranteed express delivery services will only increase. In recent years, the requirements of users have changed dramatically as people expect more product variety, next-day delivery and door-to-door delivery. To satisfy such demands, there is a need for a higher level of variety and reliability in the supply chain.

HSR can move freight in the most sustainable way and can sufficiently improve the trade links within Europe and between Europe and Asia.

Currently, the freight services in Europe are fragmented and need technical standardisation across various countries and improvement in the cooperation among different infrastructure authorities. There is a need to investigate the capability of existing HSR to transport freight and the technical and operational constraints concerning mixed traffic. Another serious constraint is the increase in the cost of the maintenance of mixed lines. The maintenance of the mixed lines is expensive and requires much longer time to be completed. However, the required maintenance and related time can be reduced by the implementation of the preventative maintenance instead of the reactive one and the use of advanced real-time sensors that continuously monitor the conditions of existing railway infrastructure and RS. This also means that it would be possible to allocate more time during the night time for freight services.

Development of suitably designed and located terminals is another constraint for freight transportation on HSR. Terminals are a place where freight enters and leaves the railway system, and they are hugely important for efficient and sustainable performance of railways. There is a need to develop road-rail-air terminals and to close any gaps in the well-linked and integrated transport network of road-rail-air-rail-road. They can be located near airports, sea ports or railway stations. However, the development of new HSR terminals may require substantial investments in the new HSR infrastructure. Most HSR stations are constructed for passenger purpose only. With the increasing demand for freight express delivery services and the introduction of freight trains using HSR, there is a need to construct new freight yards and terminals which can be located near the HSR stations or near local express distribution centres. These can be connected with the HSR through a branch line. The freight transport on 
the HSR could face a problem in terms of creating a timetable as freight trains do not follow a regular timetable. They fluctuate at short notice to meet demand, and this affects the line capacity. There are also some infrastructure constraints as high-speed freight train should be able to operate on lines with steep gradient.

To promote the shifting of freight from air to rail, it would be necessary to have the same conditions for both transportation modes. The fuel of air transport and railway transport must be taxed in the same way [40]. A sustainable transport system means that each transport user pays the full marginal cost. It will encourage the use of the infrastructure more efficiently, reduce the negative effect from transport and improve the equality among various transport modes. It will help the shifting of traffic from roads and airlines to more sustainable modes of transportation. In turn, it will bring sufficient reduction in the environmental externalities that overall will make all transport systems more sustainable.

The benefits from shifting freight from air to HSR are:

- For air transport - reduction in congestion, improvement in accessibility and punctuality, generation of new demand, overall increases in the utilisation of transport infrastructure and general improvement in airport efficiency.

- For HSR - generation of new demand, increases in load factor, overall increases in the utilisation of transport infrastructure and increases in revenue.

- For customer - reduction in cost and increases in service quality.

- For society - reduction in the transportation cost and which may increase the demand and revenue, reduction of air and noise pollution, reduction in the number of accidents, improvement of airport punctuality and capacity, improvement of the railway revenue and a reduction of HSR subsidies. The shifting of freight from air to HSR will enable the HSRs increase their loading factor and help increasing the air industry capacity whilst reducing the negative environmental impact and support fulfilling the transport industry's socialeconomic obligations. The cost and prices of purchases will decrease which will increase the demand and overall boost the economy.

Building and operating a successful HSR is an expensive business, and it looks doubtful enough that HSR operators or state-owned rail companies will be able just by themselves to establish HSR freight transportation. In order to reduce the delivery time and have coordinated timetables, the freight transportation by HSR must be part of an air transport system. It needs to have a fully controlled system possibly within one company where the HSR is part of an express logistic system. The logistic companies own airplanes and road vehicles, and therefore, it will be more logical and practical if they are able to own rail services as well. The local and regional authorities can be co-founders of new freight HSRs. Considering the fact that there is a limited sky capacity above Europe, shifting freight from air to HSR can reduce the congestion at airports, increase the HSR revenues and expand the volume of the existing airport systems.

\section{REFERENCES}

[1] Ruamsook, K., Sustainable freight transportation: a review of strategies, Ageconsearch. umn.edu, Available at http://ageconsearch.umn.edu/bitstream/207083/2/2012_38_ Freight_Transport_Strategies.pdf, 2018 (accessed 16 September 2018).

[2] Yu, X., Lang, M., Gao, Y., Wang, K., Su, C., Tsai, S., Huo, M., Yu, X. \& Li, S., An empirical study on the design of China high-speed rail express train operation plan - from 
a sustainable transport perspective. Sustainability, 10(7), p. 2478, 2018., available at https://www.researchgate.net/publication/326436685_An_Empirical_Study_on_the_ Design_of_China_High-Speed_Rail_Express_Train_Operation_Plan-From_a_Sustainable_Transport_Perspective, 2018 (accessed 16 September 2018).

[3] Huang, W. \& Shuai, B., Using improved entropy-cloud model to select high speed railway express freight train service sites. Mathematical Problems in Engineering, pp. 1-13, 2017, available at https://www.hindawi.com/journals/mpe/2017/7824835/, 2017 (accessed 16 September 2018).

[4] Liang X, Tan K, Whiteing A, Nash C, Johnson D. Parcels and mail by high speed rail - comparative analysis of Germany, France and China. Journal of Rail Transport Planning \& Management, 6(2), pp. 77-88, 2016.

[5] Pazour, J., Meller, R. \& Pohl, L., A model to design a national high-speed rail network for freight distribution. Transportation Research Part A: Policy and Practice, 44(3), pp. 119-135, 2010, available at https://www.sciencedirect.com/science/article/pii/ S0965856409001268, 2010 (accessed 16 September 2018).

[6] Behiri, W., Belmokhtar-Berraf, S. \& Chu, C., Urban freight transport using passenger rail network: scientific issues and quantitative analysis. Transportation Research Part E: Logistics and Transportation Review, 115, pp. 227-245, 2018, available at https:// www.sciencedirect.com/science/article/pii/S136655451730162X, 2018 (accessed 16 September 2018).

[7] Rita.dot.gov., | Bureau of Transportation Statistics, available at https://www.rita.dot. gov/bts/sites/rita.dot.gov.bts/files/publications/freight_shipments_in_america/html/entire.html, 2004 (accessed 18 January 2018).

[8] The Impact of the Express Delivery Industry on the global economy [Internet]. Globalexpress.org. 2005 [cited 5 November 2017], available at https://global-express.org/doc/ Global_Express_Impact_Study.pdf.

[9] IATA annual Review 2017 [Internet]. Iata.org. 2017 [cited 8 November 2017], available at https://www.iata.org/publications/Documents/iata-annual-review-2017.pdf.

[10] DHL Air Fleet Details and History [Internet]. Planespotters.net. 2017 [cited 8 November 2017], available at https://www.planespotters.net/airline/DHL-Air.

[11] Boeing 737-300F, Fast Freight Aircraft I Air Partner [Internet]. Airpartner.com. 2017 [cited 8 November 2017], available at http://www.airpartner.com/en/aircraft-guide/ boeing-b737-300f/.

[12] Rail Freight: Facts and Myths [Internet]. Freightonrail.org.uk. 2005 [cited 4 November 2017], available at http://www.freightonrail.org.uk/PDF/FactsandMyths.pdf.

[13] High speed freight - food for thought I Rail.co.uk [Internet]. Rail.co.uk. 2017 [cited 26 October 2017], available at http://www.rail.co.uk/rail-news/2013/high-speed-freightfood-for-thought/.

[14] Ruddick G. Online shopping to grow by $£ 320$ bn in three years [Internet]. Telegraph. co.uk. 2015 [cited 8 November 2017], available at http://www.telegraph.co.uk/finance/ newsbysector/retailandconsumer/11657830/Online-shopping-to-grow-by-320bn-inthree-years.html.

[15] Online Retailing: Britain, Europe, US and Canada 2017 - Centre for Retail Research, Nottingham UK [Internet]. Retailresearch.org. 2017 [cited 8 November 2017], available at http://www.retailresearch.org/onlineretailing.php.

[16] The European Express Association - Facts \& Figures on the express industry [Internet]. Euroexpress.org. 2017 [cited 8 November 2017], available at http://euroexpress.org/ facts-figures. 
[17] European Commission, Directorate-General for Trade, China [Internet]. Trade. ec.europa.eu. 2017 [cited 8 November 2017], available at http://trade.ec.europa.eu/doclib/docs/2012/march/tradoc_149251.pdf.

[18] The future of retailing - Smart Insights Digital Marketing Advice [Internet]. Smart Insights. 2017 [cited 8 November 2017], available at https://www.smartinsights.com/ ecommerce/ecommerce-strategy/the-future-of-retailing/.

[19] The impact of the Express Delivery Industry on the Global Economy [Internet]. Euroexpress.org. 2009 [cited 8 November 2017], available at http://www.euroexpress.org/ uploads/ELibrary/REPORTS.

[20] K. RZD develop plans for high-speed rail freight [Internet]. International Railway Journal. 2017 [cited 9 November 2017], available at.

[21] Icao.int, Low Cost Carriers (LCCS), available at https://www.icao.int/sustainability/ Pages/Low-Cost-Carriers.aspx, 2018 (accessed 24 December 2018).

[22] Pels, E., Nijkamp, P. \& Rietveld, P., Inefficiencies and scale economies of European airport operations. Transportation Research Part E: Logistics and Transportation Review, 39(5), pp. 341-361, 2003, available at https://www.sciencedirect.com/science/article/ pii/S1366554503000164.

[23] AirMundo, Top 10 busiest airports in Europe |AirMundo, available at https://airmundo. com/en/blog/top-10-busiest-airports-in-europe/, 2018 (accessed 24 December 2018).

[24] TripSavvy, The World's Most Delayed Major Airports, available at https://www.tripsavvy.com/the-worlds-most-delayed-airports-4074313, 2018 (accessed 24 December 2018).

[25] Ec.europa.eu, Air transport statistics - Statistics Explained, available at https:// ec.europa.eu/eurostat/statistics-explained/index.php/Air_transport_statistics, 2018 (accessed 24 December 2018).

[26] Cargofacts.com, Top 20 cargo airports in 2017 | Cargo Facts, available at https://cargofacts.com/top-20-cargo-airports-in-2017/, 2018 (accessed 24 December 2018).

[27] Albalate, D., Bel, G. \& Fageda, X., Competition and cooperation between high-speed rail and air transportation services in Europe. Journal of Transport Geography, 42, pp. 166-174, 2015, available at https://www.sciencedirect.com/science/article/abs/pii/ S0966692314001513, 2015.

[28] Ec.europa.eu, Air transport statistics - Statistics Explained, available at https:// ec.europa.eu/eurostat/statistics-explained/index.php/Air_transport_statistics\#Air_ freight_and_mail_transport:_increasing_international_transport_between_2015_ and_2016, 2018 (accessed 24 December 2018).

[29] Boeing.com, Boeing: Freighters, available at http://www.boeing.com/commercial/ freighters/, 2018 (accessed 24 December 2018).

[30] High Speed lines in the world [Internet]. Uic.org. 2017 [cited 6 November 2017], available at http://uic.org/IMG/pdf/20170901_high_speed_lines_in_the_world.pdf, 2017

[31] Ohnell, S. \& Woxenius, J., An industry analysis of express freight from a European railway perspective. International Journal of Physical Distribution \& Logistics Management, 33(8), pp. 735-751, 2003, available at https://www.emeraldinsight.com/doi/ abs/10.1108/09600030310502902?journalCode=ijpdlm.

[32] Taylor, I., La Poste to streamline courier products and invest in rail transport | Post\&Parcel, Post\&Parcel, available at http://postandparcel.info/61633/news/companies/la-poste-to-streamline-courier-products-and-invest-in-rail-transport/, 2014 (accessed 18 January 2018). 
[33] Burgen S., The Silk Railway: freight train from China pulls up in Madrid [Internet]. The Guardian. 2014 [cited 5 November 2017], available at https://www.theguardian.com/ business/2014/dec/10/silk-railway-freight-train-from-china-pulls-into-madrid, 2014.

[34] Smith, K., China-Europe rail freight continues to soar, Railjournal.com, available at http://www.railjournal.com/index.php/freight/china-europe-rail-freight-continues-tosoar.html, 2017 (accessed 18 January 2018).

[35] China considering high-speed freight trains [Internet]. Rwfreight.co.uk. 2017 [cited 10 November 2017], available at https://www.rwfreight.co.uk/news/2014/08/27/chinaconsidering-high-speed-freight-trains-123/, 2017.

[36] Troche G., High-speed rail freight, sub-report in Efficient train systems for freight transport [Internet]. Kth.se. 2005 [cited 3 November 2017], available at https://www. kth.se/polopoly_fs/1.87134!/Menu/general/column-content/attachment/0512_inlaga. pdf, 2005.

[36] Two-thirds of public support rail freight investment boost, poll finds [Internet]. Railtechnologymagazine.com. 2017 [cited 4 November 2017], available at http://www. railtechnologymagazine.com/Rail-freight/two-thirds-of-public-support-rail-freightinvestment-boost-poll-finds.

[37] Veijen, M., High-speed freight train Italy hits the track on 7 November, RailFreight. com., available at https://www.railfreight.com/railfreight/2018/11/02/high-speedfreight-train-italy-hits-the-track-on-7-november/, 2018 (accessed 24 December 2018).

[38] Two-thirds of public support rail freight investment boost, poll finds [Internet]. Railtechnologymagazine.com. 2017 [cited 4 November 2017], available at http://www. railtechnologymagazine.com/Rail-freight/two-thirds-of-public-support-rail-freightinvestment-boost-poll-finds.

[39] DHL Guide, E-commerce - DHL Guide, available at https://dhlguide.co.uk/e-commerce/, 2018 (accessed 24 December 2018).

[40] Watson, I., External costs affecting sustainability of transport systems, Arcom.ac.uk., available at http://www.arcom.ac.uk/-docs/workshops/2016-06-CHOBE-Proceedings. pdf, 2016 (accessed 26 December 2018).

[41] Watson, I., Ali, A. \& Bayyati, A., An Investigation into the Benefits and Constraints of Shifting Freight Traffic onto High-Speed Railways. 16th International Conference on Railway Engineering Design and Optimisation, Vol. 181. WIT Press: Lisbon 2018, ISSN 1743-3509. 